\title{
Mixed cultivation of legumes and cereals to strengthen the fodder base in cattle husbandry
}

\author{
$B$ Mardatov $^{1}, B$ Allashev $^{2, *}, U$ Beknaev $^{1,2}, O$ Kuchchiev $^{1,2}, R$ Khalimmetova $^{1,2}$, and $A$ \\ Sharapov ${ }^{1,3}$ \\ ${ }^{1}$ Scientific Research Institute of Cattle and Poultry Husbandry, Tashkent, Uzbekistan \\ ${ }^{2}$ Tashkent branch of Samarkand Institute of Veterinary Medicine, Zangi-ata district, Tashkent \\ province, Uzbekistan \\ ${ }^{3}$ Tashkent State Agrarian University, University str., 2, Tashkent province, 100140 Uzbekistan
}

\begin{abstract}
In order to further strengthen the fodder base in cattle husbandry, scientists of the Research Institute of Cattle husbandry and Poultry studied the variety of sorghum "Kibray" and oat variety "Uzbekistan broad-leaved" in different options, at different rates, at different times. Variations planted without a two-component mixture were tested in 4 options each. Valuable farm traits, especially green mass yield, were analyzed for each option. The cost-effectiveness of each option was also examined. An effective option for sowing Sorghum without mixing with cereals has been identified.
\end{abstract}

\section{Introduction}

One of the important conditions for the successful development of the livestock sector is the creation of a solid fodder base. In this case, the cost of livestock products is determined by the cost of feed. Proper organization of the fodder base not only develops the industry, but also is the basis for the cultivation of cheap livestock products $[1,2]$.

The areas used for fodder production in the country are limited, and most of the existing areas are saline to varying degrees, water is scarce, which requires efficient use of these lands [1-3]. However, the number of livestock in the country is growing every year. Therefore, the effective use of existing opportunities in cattle husbandry, increasing the productivity of fodder crops, the development of technologies to increase the number of feed units per hectare, the creation of new varieties and hybrids, the search for new sources of feed are urgent tasks $[3,11,12]$.

In order to increase the mass per hectare of land, research on the cultivation of sorghum in combination with cereals, the development of technology for growing sorghum in combination with cereals through the study of the most effective option, is one of the most important tasks in strengthening the base $[4,6]$.

A number of research works have been carried out on the cultivation of sorghum in combination with cereals [5-10]. In the research of GI Demidas and MV Zakhlebaev on the

\footnotetext{
*Corresponding author: allashev-b@mail.ru
} 
cultivation of sorghum in combination with annual cereals, the yield was significantly higher than in the cultivation of sorghum in pure form, ie the yield ranged from 3.1 tons $/$ ha to 8.3 tons/ha.

Thus, the aim of this research is to conduct research on the cultivation of sorghum in a mixture with cereals in order to increase the mass grown per hectare of land, to study the most effective option to grow sorghum in a mixture with cereals. For this purpose, we aimed to select the most effective option by cultivating the Kibray variety of sorghum with a mixture of oats variety "Uzbekistan broad-leaved" in different options.

\section{Materials and methods}

The experiments were conducted on the gray soils of the experimental field of the Research Institute of Cattle husbandry and Poultry. The experimental site is located in the foothills of Kibray district of Tashkent province, $15 \mathrm{~km}$ from Tashkent, at an altitude of $400 \mathrm{~m}$ above sea level.

The soil of the experimental plot is a typical gray soil with a heavy mechanical composition, which has long been irrigated. According to the results of agrochemical analysis, the amount of humus in the drive part of the soil is $1.02-1.59 \%$. The amount of useful macronutrients in the plowed soil to a depth of $0-30 \mathrm{~cm}$ is as follows: total nitrogen content $0.14-0.29 \%$, mobile phosphoric acid $\left(\mathrm{R}_{2} \mathrm{O}_{5}\right)-0.31 \mathrm{mg} / \mathrm{kg}$, exchangeable potassium $-333 \mathrm{mg} / \mathrm{kg}$.

The color of the driving part of the soil $(25-30 \mathrm{~cm})$ is dark grayish-gray, the underlying part of the soil $(30-40 \mathrm{~cm})$ is relatively dense yellowish-gray, rain worms are found at a depth of 60-65 cm. The climate of the experimental plot is characterized by hot summers, dry, very cold winters, and relatively rainy spring. The spring evening frost falls on March 25-31, and the autumn frost falls on October 18-25 as well as non-cold days are 190-200 days. The experiments were performed in 4 iterations of Sorghum without a 2-component mixture.

\section{Results and discussion}

Oats were studied by sowing in 4 iterations in 3 different options of sorghum. Each option of sowing Sorghum without a mixture of cereals was analyzed on a separate iteration and their average was calculated.

Table 1 below shows the yields and yields obtained from the first iteration of the experiments planted with a mixture of oats with oats. It can be seen from the data in the table that the control yield in Kashgar was 318.8 tons/ha when planted separately at the rate of $20 \mathrm{~kg} / \mathrm{ha}$. Oat seeds are sown with a mixture of $40 \mathrm{~kg} / \mathrm{ha}$ with sorghum at a rate of 341.6 tons $/ \mathrm{ha}$, at a rate of $60 \mathrm{~kg} / \mathrm{ha}$ at a rate of $370.4 \mathrm{tons} / \mathrm{ha}$, at a rate of $80 \mathrm{~kg} / \mathrm{ha}$ at a rate of 415.2 tons/ha. When Sorghum is sown separately, the yield is 318.8 quintals $(\mathrm{q}) / \mathrm{ha}$, oat seeds are sown in the norm of $40 \mathrm{~kg} / \mathrm{ha},+22.8 \mathrm{q} / \mathrm{ha}$, in the norm of $60 \mathrm{~kg} / \mathrm{ha}+51.6 \mathrm{q} / \mathrm{ha}, 80$ $\mathrm{kg} / \mathrm{ha}$ when added, an additional yield of $+96.4 \mathrm{q} / \mathrm{ha}$ was achieved. 
Table 1. Yields and yields from the first iteration of experiments planted with a mixture of Sorghum with oats.

\begin{tabular}{|c|c|c|c|c|c|c|c|c|c|c|c|}
\hline \multirow{2}{*}{\begin{tabular}{c|}
$\#$ \\
\\
\\
1
\end{tabular}} & \multirow{2}{*}{$\begin{array}{l}\text { Options } \\
\text { Sorghum }\end{array}$} & \multicolumn{8}{|c|}{ Taken samples, kg } & \multirow{2}{*}{$\frac{0}{79.7}$} & \multirow{2}{*}{ 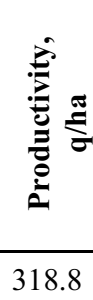 } \\
\hline & & 13 & 9.6 & 11.9 & 9.8 & 11.7 & 14.8 & 8.9 & - & & \\
\hline 2 & $\begin{array}{c}\text { Sorghum } \\
\text { +oat-40 }\end{array}$ & 9 & 11.8 & 12 & 9.2 & 13.8 & 13.7 & 15.9 & - & 85.4 & 341.6 \\
\hline 3 & $\begin{array}{c}\text { Sorghum } \\
+ \text { oat- } 60\end{array}$ & 15.4 & 11.9 & 11.3 & 18.6 & 13.1 & 11.8 & 10.5 & - & 92.6 & 370.4 \\
\hline 4 & $\begin{array}{l}\text { Sorghum } \\
\text { +oat- } 80\end{array}$ & 15.1 & 9.6 & 11.9 & 9.8 & 11.7 & 14.8 & 16.1 & 14.8 & 103.8 & 415.2 \\
\hline
\end{tabular}

Table 2 shows the yields and yields obtained from the second iteration of experiments in which sorghum was planted in a mixture with cereals. It can be seen from the data in the table that the control yield in Kashgar was $328.4 \mathrm{q} / \mathrm{ha}$ when planted separately at the rate of $20 \mathrm{~kg} / \mathrm{ha}$. In Kashgar, oat seeds are sown with a mixture of $40 \mathrm{~kg} / \mathrm{ha}$ at a rate of 347.6 tons $/ \mathrm{ha}$, at a rate of $60 \mathrm{~kg} / \mathrm{ha}$ at a rate of $378.8 \mathrm{tons} / \mathrm{ha}$, at a rate of $80 \mathrm{~kg} / \mathrm{ha}$ at a rate of 404.8 tons/ha. yielding. When Sorghum is sown separately, the yield is $328.4 \mathrm{q} / \mathrm{ha}$, oat seeds are sown at the rate of $+19.2 \mathrm{q} / \mathrm{ha}$, at the rate of $60 \mathrm{~kg} / \mathrm{ha}$ at the rate of $+50.4 \mathrm{q} / \mathrm{ha}$, at the rate of $80 \mathrm{~kg} / \mathrm{ha}$. when added, an additional yield of $+76.4 \mathrm{q} / \mathrm{ha}$ was achieved.

Table 2. Yields from the second iteration of experiments planted with a mixture of Sorghum with oats.

\begin{tabular}{|c|c|c|c|c|c|c|c|c|c|c|}
\hline \# & Options & \multicolumn{7}{|c|}{ Taken samples, kg } & 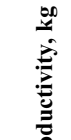 & 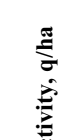 \\
\hline 1 & Sorghum & 17.5 & 14.7 & 10.3 & 14.1 & 13.2 & 12.3 & - & 82.1 & 328.4 \\
\hline 2 & $\begin{array}{c}\text { Sorghum }+o \\
\text { at- } 40\end{array}$ & 18.6 & 16.7 & 19.2 & 14.2 & 18.2 & - & - & 86.9 & 347.6 \\
\hline 3 & $\begin{array}{c}\text { Sorghum }+o \\
\text { at-60 }\end{array}$ & 14.7 & 10.1 & 15.2 & 16.1 & 10.2 & 13.6 & 14.8 & 94.7 & 378.8 \\
\hline 4 & $\begin{array}{c}\text { Sorghum }+o \\
\text { at- } 80\end{array}$ & 11.8 & 18.2 & 10.2 & 17.6 & 11.3 & 15.2 & 16.9 & 101.2 & 404.8 \\
\hline
\end{tabular}

Table 3 shows the yields and yields obtained from the third iteration in experiments planted with a mixture of oats with oats. From the data given in the table, it can be seen that the control yield in Kashgar was $339.6 \mathrm{q} / \mathrm{ha}$ when planted separately at the rate of $20 \mathrm{~kg} / \mathrm{ha}$. In Kashgar, oat seeds are sown with a mixture of $40 \mathrm{~kg} / \mathrm{ha}$ at a rate of 345.6 tons $/ \mathrm{ha}$, at a rate of $60 \mathrm{~kg} / \mathrm{ha}$ at a rate of 388.8 tons $/ \mathrm{ha}$, at a rate of $80 \mathrm{~kg} / \mathrm{ha}$ at a rate of $414.4 \mathrm{tons} / \mathrm{ha}$. yielding. When Sorghum is sown separately, the yield is 339.6 tons/ha, oat seeds are 40 $\mathrm{kg} / \mathrm{ha},+6.0$ tons $/ \mathrm{ha}, 60 \mathrm{~kg} / \mathrm{ha},+49.2$ tons $/ \mathrm{ha}, 80 \mathrm{~kg} / \mathrm{ha}$. when added, an additional yield of $+74.8 \mathrm{q} / \mathrm{ha}$ was achieved. 
Table 3. Yields from the third iteration of experiments planted with a mixture of Sorghum with oats.

\begin{tabular}{|c|c|c|c|c|c|c|c|c|c|c|c|}
\hline \# & Options & \multicolumn{8}{|c|}{ Taken samples, kg } & \multirow{2}{*}{ 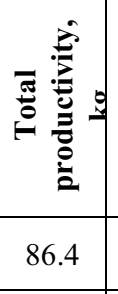 } & \multirow{2}{*}{ } \\
\hline 1 & $\begin{array}{c}\text { Sorghum }+ \text { oat- } \\
40 \\
\end{array}$ & 8.3 & 8.4 & 9.5 & 13.1 & 14.2 & 10.4 & 11.7 & 10.8 & & \\
\hline 2 & $\begin{array}{c}\text { Sorghum+oat- } \\
60\end{array}$ & 12.6 & 10.2 & 11.5 & 12.8 & 14.5 & 13.2 & 12.6 & 9.8 & 97.2 & 388.8 \\
\hline 3 & $\begin{array}{c}\text { Sorghum+oat- } \\
80\end{array}$ & 14.9 & 13.8 & 14.8 & 10.8 & 15.3 & 11.6 & 11.7 & 10.7 & 103.6 & 414.4 \\
\hline
\end{tabular}

Table 4 shows the yields and yields obtained from the fourth iteration in experiments planted with a mixture of oats with oats. According to the data in the table, the control yield in Kashgar was $349.6 \mathrm{q} / \mathrm{ha}$ when planted separately at the rate of $20 \mathrm{~kg} / \mathrm{ha}$. In Kashgar, oat seeds are sown with a mixture of $40 \mathrm{~kg} / \mathrm{ha}$ at a rate of 350.8 tons $/ \mathrm{ha}$, at a rate of $60 \mathrm{~kg} / \mathrm{ha}$ at a rate of 386.4 tons $/$ ha, at a rate of $80 \mathrm{~kg} / \mathrm{ha}$ at a rate of 424.4 tons/ha. yielding. When Sorghum is sown separately, the yield is $349.6 \mathrm{q} / \mathrm{ha}$, oat seeds are sown with the addition of $40 \mathrm{~kg} / \mathrm{ha},+1.2 \mathrm{q} / \mathrm{ha}$, with the addition of $60 \mathrm{~kg} / \mathrm{ha},+36.8 \mathrm{q} / \mathrm{ha}, 80 \mathrm{~kg} / \mathrm{ha}$. when added, an additional yield of $+74.8 \mathrm{q} /$ ha was achieved.

Table 4. Yields from the fourth iteration of experiments planted with a mixture of Sorghum with oats.

\begin{tabular}{|c|c|c|c|c|c|c|c|c|c|c|c|c|}
\hline \# & Options & \multicolumn{9}{|c|}{ Taken samples, kg } & \multirow{2}{*}{ 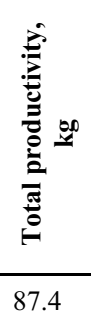 } & \multirow{2}{*}{ 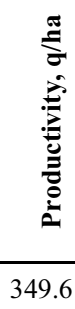 } \\
\hline 1 & Sorghum & 10.5 & 8.6 & 12.8 & 8.9 & 9.1 & 7.3 & 8.9 & 6.1 & 15.2 & & \\
\hline 2 & $\begin{array}{l}\text { Sorghum+ } \\
\text { oat-40 }\end{array}$ & 10.5 & 11.2 & 19 & 9.1 & 9.1 & 5.4 & 5.5 & 9.6 & 8.3 & 87.7 & 350.8 \\
\hline 3 & $\begin{array}{c}\text { Sorghum+ } \\
\text { oat-60 }\end{array}$ & 10.6 & 9.6 & 11.5 & 10.6 & 17.6 & 10.1 & 11.3 & 15.3 & - & 96.6 & 386.4 \\
\hline 4 & $\begin{array}{c}\text { Sorghum+ } \\
\text { oat-80 }\end{array}$ & 14.7 & 12.7 & 15.6 & 13.9 & 17.1 & 11.8 & 10.9 & 9.4 & - & 106.1 & 424.4 \\
\hline
\end{tabular}

Each option of sowing sorghum without a mixture with oats was analyzed on separate iterations and their average was calculated. The mean yields at 4 iterations for each variant are given in Table 5 below.

Thus, it can be seen from the table that when sorghum sown separately, $334.1 \mathrm{q} / \mathrm{ha}$, oat seeds are sown in the norm of $346.4 \mathrm{q} / \mathrm{ha}$, in the norm of $60 \mathrm{~kg} / \mathrm{ha}$, in the norm of 381.1 $\mathrm{q} / \mathrm{ha}$, in the norm of $80 \mathrm{~kg} / \mathrm{ha}$, while the yield was $414.7 \mathrm{q} / \mathrm{ha}$. 
Table 5. Yields obtained when sorghum mixed with oats in different proportions.

\begin{tabular}{|c|c|c|c|c|c|c|}
\hline \# & Options & 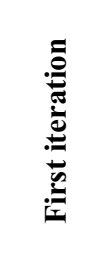 & 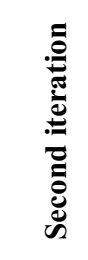 & 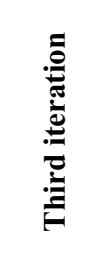 & 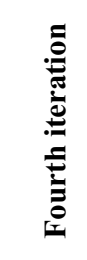 & 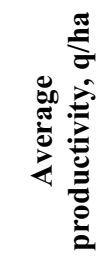 \\
\hline 1 & Sorghum & 318.8 & 328.4 & 339.6 & 349.6 & 334.1 \\
\hline 2 & Sorghum + oat -40 & 341.6 & 347.6 & 345.6 & 350.8 & 346.4 \\
\hline 3 & Sorghum + oat -60 & 370.4 & 378.8 & 388.8 & 386.4 & 381.1 \\
\hline 4 & Sorghum + oat -80 & 415.2 & 404.8 & 414.4 & 424.4 & 414.7 \\
\hline
\end{tabular}

The cost-effectiveness indicators of growing Sorghum in a mixture with oats were analyzed and are presented in Table 6 below. It can be seen from the data in the table that high efficiency was achieved when oat seeds were sown in a mixture with oats in Sorghum at a rate of $80 \mathrm{~kg} / \mathrm{ha}$.

Table 6. Cost-effectiveness of growing Sorghum in combination with oat.

\begin{tabular}{|c|c|c|c|c|}
\hline \multirow{2}{*}{$\mathrm{C}_{\text {Indicators }}^{\text {Options }}$} & \multirow{2}{*}{$\begin{array}{c}\text { Control } \\
\text { (sorghum } 20 \\
\text { kg) }\end{array}$} & \multicolumn{3}{|c|}{ Oat } \\
\hline & & $\begin{array}{c}40 \\
\mathrm{~kg} / \mathrm{ha}\end{array}$ & $\begin{array}{c}60 \\
\mathrm{~kg} / \mathrm{ha}\end{array}$ & $\begin{array}{c}80 \\
\mathrm{~kg} / \mathrm{ha}\end{array}$ \\
\hline Productivity, $\mathrm{q} / \mathrm{ha}$ & 334.1 & 346.4 & 381.1 & 414.7 \\
\hline $\begin{array}{l}\text { Additional yield in accordance } \\
\text { with the control, } \mathrm{q} / \mathrm{ha}\end{array}$ & - & 12.3 & 47 & 80.6 \\
\hline $\begin{array}{l}\text { Additional yield in accordance } \\
\text { with the control, } \%\end{array}$ & - & 103.7 & 114.1 & 124.1 \\
\hline $\begin{array}{l}\text { Cost of one green mass, ' } 000 \\
\text { UZS }\end{array}$ & 20 & 20 & 20 & 20 \\
\hline $\begin{array}{l}\text { Income of one green mass, ' } 000 \\
\text { UZS }\end{array}$ & 6,682 & 6,928 & 7,622 & 8,294 \\
\hline $\begin{array}{l}\text { Profit from additional yield, } \\
\text { '000 UZS }\end{array}$ & - & 246 & 940 & 1,612 \\
\hline $\begin{array}{l}\text { Cost of operations, '000 } \\
\text { UZS/ha }\end{array}$ & 1,500 & 1,500 & 1,500 & 1,500 \\
\hline $\begin{array}{l}\text { Cost of sorghum seeds, '000 } \\
\text { UZS }\end{array}$ & 400 & 400 & 400 & 400 \\
\hline $\begin{array}{l}\text { Cost of additional seeds, ' } 000 \\
\text { UZS }\end{array}$ & & 160 & 240 & 320 \\
\hline Total costs, '000 UZS & 1,900 & 2,060 & 2,140 & 2,220 \\
\hline Net profit, '000 UZS/ha & 4,782 & 4,868 & 5,482 & 6,074 \\
\hline $\begin{array}{l}\text { Additional net profit in } \\
\text { accordance with the control } \\
\text { option, } 600 \mathrm{UZS} / \mathrm{ha}\end{array}$ & $\mathbf{0}$ & 86 & 700 & 1,292 \\
\hline
\end{tabular}


In the study, experiments were performed at different times to determine the optimal timing of planting. Thus, the experiments were conducted in 5 iterations, i.e., in 1 iteration in September 1, September 15, September 30, October 15, and October 30, in total 4 iterations.

The yield of green mass when Sorghum is sown at different times without a mixture with oats is given in Table 7 below.

Table 7. Indicators of green mass yield obtained when sowing Sorghum with oats at different iterations.

\begin{tabular}{|c|c|c|c|c|c|c|c|}
\hline \# & Sowing dates & : & 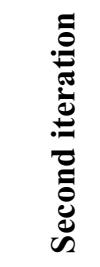 & 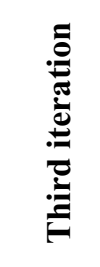 & 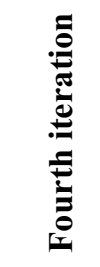 & $X \pm S x$ & $C v \%$ \\
\hline 1 & September 1 & 414.6 & 420.4 & 412.8 & 409.6 & $414.4 \pm 0.4$ & 9.8 \\
\hline 2 & September 15 & 405.8 & 411.2 & 410.6 & 412.6 & $410.1 \pm 0.6$ & 8.2 \\
\hline 3 & $\begin{array}{c}\text { September } 30 \\
\text { (cont.) }\end{array}$ & 410.4 & 408.4 & 401.2 & 400.6 & $405.8 \pm 0.8$ & 10.6 \\
\hline 4 & October 15 & 407.2 & 392.4 & 384.6 & 390.7 & $393.7 \pm 0.9$ & 12.1 \\
\hline 5 & October 30 & 390.3 & 378.7 & 381.4 & 379.4 & $382.5 \pm 0.5$ & 9.6 \\
\hline
\end{tabular}

From the data given in the table, we can see that Sorghum without oats was sown in early September at 414.4 tons/ha, in mid-September at 410.1 tons/ha, in late September, at the beginning of October at 405.8 tons/ha, in October. The yield was $393.7 \mathrm{q} / \mathrm{ha}$ when sown in mid-October and $382.5 \mathrm{q} / \mathrm{ha}$ when sown in late October.

During the month of September, i.e. at the beginning, middle and end of the month, there is no significant difference in the yields of blue mass. But since October, we can see that the chart of indicators on green mass yield is declining. This means that this twocomponent compound option should be planted as early as possible in September.

\section{Conclusions}

Thus, it can be concluded that when oats were studied in different options, the highest value was obtained in the variant where oats were added at a rate of $80 \mathrm{~kg} / \mathrm{ha}$. At the same time, an additional $80.6 \mathrm{q} / \mathrm{ha}$ or $24.1 \%$ more sorghum was harvested than in the previous year. At the same time, the economic efficiency was good, with an additional income of 1,292,000 UZS per hectare. The lowest rate was when oats were planted at a rate of $40 \mathrm{~kg} / \mathrm{ha}$. At the same time, the sorghum yield was $12.3 \mathrm{q} / \mathrm{ha}$ or only $3.7 \%$ more than in the past. The economic efficiency of this option was also low, with an additional income of 86,000 UZS/ha. The sorghum yield was $334.1 \mathrm{q} / \mathrm{ha}$ when it was planted cleanly. In the study on sowing of Sorghum oats at different times, high yields were achieved when sowing on September 1, ie $414.4 \mathrm{q} / \mathrm{ha}$. When planted on October 30 , the yield fell to $382.4 \mathrm{q} / \mathrm{ha}$ or 32 $\mathrm{q} /$ ha. In percentage terms, yields decreased by 7.8 percent in late October compared to those planted in early September.

\section{References}

1. M. Ashirov, U. Soatov, Journal of Zootechnics, 8, 19-20 (2015) 
2. S. Karamfilov, V. Nikolov, R. Malinova, Bulgarian Journal of Agricultural Science, 25(6), 1254-1260 (2019)

3. M. Ashirov, Y. Nasirdinov, B. Ashirov, F. Bakhriddinov, Journal of Dairy and beef cattle breeding, 4, 23 (2019)

4. B. Zavertyayev, P. Prokhorenko, Journal of Zootechnics, 8, 8-12 (2000)

5. U. Soatov, M. Ashirov, Journal of Dairy and beef cattle breeding, 6, 21-23 (2019)

6. U. Soatov, M. Ashirov, An International Multidisciplinary Research Journal, 10(8), 177-182 (2020)

7. S. K. Isaev, R. U. Rakhmonov, S. S. Tadjiev, G. I. Gozeiv, S. Z. Khasanov, In IOP Conference Series: Earth and Environmental Science, 614(1), 012147 (2020)

8. B. Sh. Matyakubov, Z. J. Mamatkulov, R. K. Oymatov, U. N. Komilov, G. E. Eshchanova, InterCarto, InterGIS, 26, 229-239 (2020)

9. N. Ch. Namozov, D. A. Kodirova, M. I. Usmonova, International journal of scientific \& technology research, 9(03), 5491-5493 (2020)

10. S. Isaev, S. Khasanov, Y. Ashirov, T. Karabaeva, A. Gofirov, In E3S Web of Conferences, 244, 02012 (2021)

11. A. Bouisfi, F. Bouisfi, M. Chaoui, FME Transactions, 47(1), 129-134 (2019)

12. R. Malinova, V. Nikolov, Bulgarian Journal of Agricultural Science, 25(4), 756-761 (2019) 